\title{
Diego Mariño Sánchez, Injertando a Dioniso. Las interpretaciones del dios, de nuestros días a la Antigüedad. Madrid: Siglo XXI, 2014, 414 págs.
}

Comenzaré por decir que, para la crítica moderna, Dioniso era el más importante de todos los dioses en la antigua religiosidad griega. Esta afirmación puede sonar demasiado audaz en el marco de un panteón griego gobernado por dioses cívicos, políticos y celestes tan relevantes como el próvido Zeus o el sagaz flechador Apolo. Pero es Dioniso, acaso por su especial interacción con los seres humanos, la divinidad que hoy se nos antoja más interesante para una historia social y cultural de la antigua religión griega. Es el dios que, en cierto modo, acercaba a los hombres a la categoría divina, ya fuera mediante un proceso extático de deificación temporal o a través de sus renombrados misterios. Hijo de Zeus y de la mortal Sémele, que muere abrasada por el rayo al pedir a su divino amante que se le mostrara como dios y gestado por su padre desde entonces en su muslo, Dioniso muestra ya en sus orígenes esa dualidad entre lo divino y lo humano: el dos veces nacido, la primera vez, del fuego de su padre, un viejo procedimiento mítico para otorgar inmortalidad, y la segunda, directamente del muslo del dios más poderoso. Dioniso nace dios, pero habrá de pasar una larga y compleja peripecia hasta lograr su reconocimiento final entre hombres primero y luego entre dioses (así, no es extraño que sus mitos se dividan entre los de hospitalidad o theoxenía de sus dones y los de resistencia de los theomachoi, que se oponen a sus ritos). Muy pronto Hera, esposa de Zeus, celosa contra el nuevo hijo bastardo de su marido, hará de Dioniso un dios loco (mainómenos), que vagará por el mundo produciendo locura y extrañamiento entre las mujeres con su cortejo de sátiros y ménades enloquecidas (mainades), regentando sus rituales extáticos para ambos sexos, de bacchoi y bacchai ("dicen en cuanto a los misterios: 'Muchos son los portadores de férulas, pero pocos los bacchoi”, como dice Platón en Fedro 69c-d).

Que Dioniso es el dios más importante de la Grecia antigua, así pues, es una clara reconstrucción que hacemos desde nuestros días en torno a una figura divina tan fascinante como compleja e inabarcable. A esta reconstrucción académica contribuye sin lugar a dudas la enorme recepción del dios, sus funciones, sus símbolos y, sobre todo, sus interpretaciones y adaptaciones, a la que se dedica ahora un nuevo libro. Bajo el sugerente título Injertando a Dioniso, una metáfora hortelana que alude a las lecturas y relecturas dionisíacas desde la antigüedad a nuestros días, Diego Mariño Sánchez confirma con fundamentos historiográficos la primera aseveración que se ha hecho en estas líneas sobre Dioniso. Y es que la deidad, que de forma simplista podría ser llamada dios del vino o, con más amplitud y justicia, del éxtasis, la embriaguez y el extrañamiento místico, se especializó siempre en procurar otra visión del yo y de lo otro. Al sacar de sí mismos a los seres humanos, haciéndoles perder la conciencia de su condición efímera, de las circunstancias que les rodeaban, y trasportándolos más allá de su realidad y de lo cotidiano mediante la apasionante experiencia que patrocinaba, en lo religioso y también en lo poético-escénico, la potencia hermenéutica de Dioniso se desató ya de forma imparable desde los antiguos textos: véase por ejemplo la poderosa impresión que deja la obra Bacantes de Eurípides, compuesta en el contexto sociopolítico de la Atenas democrática, de esos ritos "al son de panderos de sordo retumbo, festejando con gritos de ¡evohé! al dios" (en la estupenda traducción de C. García Gual), y de esa ciudad de Tebas que es la "ciudad de Dioniso", como titulaba V. Leinieks su estudio de 1996 sobre aquel inolvidable drama. 
La inspiración que implicaba la religión dionisíaca estaba concebida como una forma de participar de la divinidad mediante un cierto delirio que no era, por cierto, estrictamente resultante de la ingesta de vino u otras sustancias, sino que tenía otras causas psicológicas. El "menadismo", como se ha venido en llamar desde A. Rapp, E. Robins y E.R. Dodds o, más recientemente, A. Henrichs (que ha mostrado cómo trasciende la categoría del mito y está histórica y epigráficamente atestiguado), implica un éxtasis frenético, una extraordinaria fuerza física y un estado de percepción exaltado, de todo punto necesarios para los ritos dionisíacos, para la oreibasía, el sparagmós o la omophagia, si tales fueron en verdad algunas de las partes de estos rituales que, por lo demás, siguen siendo oscuros. Las ménades o bacantes, mujeres del culto del dios ("Dionysos ist vorzugsweise der Frauen Gott", como ya veía Bachofen en Das Mutterrecht, 1861), eran capaces de alcanzar el delirio del dios, despedazar animales con sus manos desnudas y albergar al dios en lo más, en una suerte de íntima conexión con las fuerzas divinas de la naturaleza. El éxtasis dionisíaco era una orgía de música y de danza, una experiencia al mismo tiempo individual y colectiva, una vivencia personal, pero contagiosa: un fenómeno de masas y de espacios abiertos, que tenía su repetición a pequeña escala privada en los misterios, desde el punto de vista religioso, y en algunos simposios, desde el punto de vista cívico. Fue necesario desde la filosofía griega a la teología cristiana dar cuenta de esta multiforme experiencia: y la posteridad se empeñó en modelarla según cada conveniencia.

A la interpretación de este complejo dios -especialmente desde Nietzsche a esta parte, pero atendiendo también a sus precedentes lejanos o inmediatos- dedica ahora Mariño Sánchez este erudito estudio que proviene de su tesis doctoral y que presenta una estructura tripartita: la primera parte lleva por título "Nietzsche y el nacimiento de lo dionisíaco", la segunda "De Nietzsche a nuestros días" y la tercera "Los otros Dionisos. De la Antigüedad al siglo XVIII". La categoría historiográfica de "lo dionisíaco", fundamental, como bien señala Diego Mariño, para la configuración de la modernidad, se va analizando así a lo largo de sus páginas a partir de las aportaciones de filólogos clásicos, historiadores de la religión, psicólogos y filósofos hasta tender al fin una mirada retrospectiva hacia las diversas versiones que ya existieron en los autores del mundo grecorromano. Es una larga historia que indefectiblemente, como es obvio, ha de acabar remitiendo a la propia antigüedad, a los filósofos, especialmente neoplatónicos, y a los últimos paganos en coexistencia ya con los cristianos (fue Dioniso el alter Christus por excelencia de la antigüedad tardía, como ha mostrado en la iconografía de los mosaicos Daszewski en su Dionysos der Erlöser). En una fecunda dinámica posterior, esa historiografía de Dioniso será revitalizada con especial fuerza a partir del romanticismo alemán -también el par Dioniso-Cristo, como en el Brod und Wein de Hölderlin- y desde Nietzsche nutrirá diversas reflexiones filosóficas y antropológicas de muy hondo calado para la modernidad.

Se podría decir que la potencia poética y hermenéutica de Dioniso en la cultura y la sociedad griega $-\mathrm{y}$ por extensión en la nuestra- se mide de una doble manera: por su ausencia y su presencia. Como dios de la otredad y de la máscara, además de los numerosos festivales ciudadanos en su honor, de las Antesterias a las Dionisias Rurales y Urbanas, su mención o el silencio sobre su figura es la marca que nos indica su acción sobre la realidad griega: desde que Homero cita al dios como gozo para los mortales a su escueta presencia en Hesíodo o hasta que en las citadas Bacantes el gran Eurípides dejó entrever algo de los misterios que tanta aceptación tuvieron en la Grecia clásica y, 
luego, en las épocas helenística y romana. Dioniso fue siempre "der kommende Gott", como dijera Hölderlin en el poema citado, en una expresión que consagraría el estudioso del dionisimo Walter Otto en su conocido libro de 1933 Dionysos: Mythos und Kultus: el que entra en el ámbito de la sociedad regulada por la norma, rompiendo la rutina y trastocándolo todo. Y de hecho, durante un largo periodo de tiempo su vieja figura mítica se perfilaba como la de un dios extranjero, tracio o frigio, con lo que sus mitos de muerte y resurrección se hacían pasar por no helénicos y la filología clásica alemana salvaba la recta racionalidad de los griegos (eso implicaba, en el fondo, la Psyche de Rohde). Pero gracias al desciframiento en 1953 del Lineal B se vio que Dioniso estaba atestiguado en los documentos de Pilos, en el s. XIII a.C. Era un viejo dios griego, acaso el más importante de todos, si se me permite la reiteración. Como símbolo de vida indestructible, glosando la célebre obra de Kerényi (1976), en la literatura griega, como el hermano de Apolo que reina alternativamente en Delfos, Dioniso aparece y desaparece en la cultura griega, a veces visible, a veces subterráneo, pero siempre dejando una huella de su presencia. No en vano, el teatro pertenece a los dominios de este dios de la máscara, el engaño, la locura y la ficción. De ahí la fascinación del dios en la modernidad cuando, según la convincente taxonomía de A. Henrichs que recoge Mariño aquí, Dioniso pase a encarnar la pérdida del yo, el sufrimiento y la violencia.

Pero la problemática experiencia de lo dionisíaco, creo, se puede sondear en su condición ambivalente entre lo visible y lo invisible, los márgenes y el centro, lo que también se confirma desde el comienzo de su recepción moderna con El Nacimiento de la Tragedia de Nietzsche en 1872, al que Mariño dedica toda la primera parte de su estudio. Sin embargo, el dionisismo ofrecerá resistencia a todas las racionalizaciones, antiguas, decimonónicas y modernas, por la polifonía de manifestaciones literarias, iconográficas y filosóficas que ha implicado desde su aparición en época histórica. Como se evidencia en las páginas de este libro, Dioniso sigue representando hoy el intento inasible y siempre en progreso de comprender al ser humano. Desde Nietzsche y sus inmediatos precursores, toda época de cambio ha conllevado una nueva interpretación del dionisismo: pienso en Walter Pater en la época victoriana, los ritualistas de Cambridge tras la Primera Guerra Mundial, Walter Otto poco antes del auge del nazismo, Jeanmaire en la posguerra francesa, Kerényi desde la psicología jungiana, Girard en su concepción de la violencia, Detienne en el marco de la escuela de París tras el 68 francés, las relecturas de las Bacantes en la cultura de las drogas y el amor libre en la escena de la performance neoyorquina de Schechner... hasta llegar al Dioniso de Richard Seaford (2006), una suerte de Dioniso post 11-S con una síntesis interesante para el uso de la postmodernidad.

En su libro, de forma sugerente, Mariño ha optado, en vez de empezar con lo antiguo, por acabar con ello, emprendiendo su recorrido con Nietzsche y su Geburt der Tragödie como piedra de toque de las interpretaciones modernas sobre Dioniso y "lo dionisíaco", fundamentada en Schelling o Schlegel (no olvidemos al Dioniso poetizado de Hölderlin). El periplo dionisíaco que propone este libro, de amplias lecturas y clara erudición filosófica, es muy dilatado: Metrodoro de Lámpsaco, los neoplatónicos, Schelling, Creuzer, Nietzsche, Rohde, Harrison, Otto, Kerényi, Dodds, Jeanmaire, Vernant, Segal, Privitera, Daraki, Detienne, y otros autores que han seguido la senda de "lo dionisíaco" tratando de aprehender lo que de cierto podemos saber sobre un UrDionysos que, a veces, parece más bien una construcción historiográfica, filológica, sociológica o filosófica pensada para adaptarse a la mentalidad de cada momento y al 
contexto histórico. Dionysos multos habemus, diría Cicerón en su De natura deorum, y tantos, en efecto, como estudiosos o poetas que han tratado de definir "lo dionisíaco", añadiría yo, como rasgo de identidad del hombre, el pensador o el creador de cada época. Coincidimos en esto con la metáfora que propone Mariño: diríase que Dioniso se "injerta" en cada perspectiva hermenéutica. Y, a veces más allá de las fuentes o los testimonios, presenta diversas propuestas sobre su significado originario o fundamental. Unas versiones que desde un punto de vista histórico pueden resultar en ocasiones forzadas y, como se ve a lo largo de este libro, tienen mucho que ver con los intereses filosóficos, psicológicos, sociológicos o antropológicos de cada intérprete.

Además del gran mérito general que este libro tiene ya de por sí como conspectus de las modernas interpretaciones dionisíacas, puede afirmarse que resulta especialmente brillante en sus dos primeras partes. Se evidencia en ellas el dominio de las fuentes modernas y de las diversas teorías enunciadas, además de un discurso eficaz y bien trabado. Se ve claramente, en mi opinión, que, además de su formación en la excelente escuela de José Carlos Bermejo Barrera en historia de las religiones antiguas en teoría de la Historia, el autor se ha beneficiado en su investigación de su trabajo en el marco de la cultura académica alemana, gracias a sus estancias en la ciudad de Berlín, donde varios estudiosos se dedican precisamente a este tema. Allí, en particular, se desarrolla un interesantísimo proyecto bajo el sugerente título Der differente Gott: Der differente Gott. Konstruktionen des Dionysos in der Moderne (en el marco de la macroárea de investigación o Sonderforschungsbereich, financiada por la Deutsche Forschungsgemeinschaft, que lleva el nombre de "Transformationen der Antike"), dirigido por la catedrática de historia de las religiones Renate Schlesier, del Institut für Religionswissenschaft de la Universidad Libre de Berlín. Así, en el hilo de las construcciones dionisíacas de la modernidad, son muy destacables las páginas que dedicada Mariño Sánchez a las interpretaciones de Dodds, Vernant, Detienne, Gernet, Daraki o Seaford, por ejemplo. Su prosa las hace accesibles y claras, las recoge y las explica entrelazándolas en su propósito historiográfico. La bibliografía a ese respecto está completa y actualizada y se demuestra un admirable manejo de ella.

No se puede decir lo mismo quizá de la tercera parte del libro, la dedicada a la antigüedad. Tal vez esto se deba a los propios intereses del autor, más centrados en lo moderno. Aunque el discurso es aquí también sugerente y bien hilado, se notan algunas carencias bibliográficas y de referencias, siendo las que hay citadas algo parciales o antiguas. Se echa en falta, por ejemplo, algunos estudios clave o recientes sobre los tratamientos de Dioniso -o del dionisismo como parte clave del tardopaganismo- en la época imperial romana y, especialmente, en la llamada antigüedad tardía, cuando se da la forzada convivencia del dios de la viña con su pujante rival Cristo, tanto en iconografía y literatura como incluso en el culto. (Pienso en Accorinti-Chuvin, Bruhl, Bowersock, Cameron, Cazanove, Daszewski, Gigli, Merkelbach, Massa -demasiado reciente este, pero digno de ser añadido en una posterior edición- o Shorrock, entre otros, y también en las interpretaciones, ediciones y traducciones más recientes y actualizadas de las teorías dionisíacas de Plutarco, Diodoro, Clemente de Alejandría y, sobre todo, de Nono de Panópolis, el gran épico tardoantiguo que tiene el mérito de haber poetizado para su época a Dioniso y a Cristo a la vez y al que se ha prestado especial atención crítica últimamente en Europa y en todo el mundo académico).

Pero, ciertamente, esto no obsta para que este libro sea una aportación de primer orden y se deba convertir en un estudio de referencia para las interpretaciones y lecturas 
de "lo dionisíaco" como clave simbólica del Nachleben del dios de la máscara y la embriaguez. Tras pasar revista a tal cantidad de tesis diversas, antiguas y modernas -a esos efectos, como digo, ya es un compendio imprescindible para el estudioso-, el autor no aventurará una interpretación propia del dionisismo y de "lo dionisíaco": prefiere centrar sus conclusiones en una explicación del mito de Dioniso como una suerte de catalizador histórico-cultural que, desde cada uno de los presentes, posibilita la comprensión y reconstrucción del pasado. El mito, como en lo antiguo, facilita alusiones, evocaciones y alegorías en torno a verdades subyacentes que cada intérprete intentará desarrollar, descifrando, revitalizando o, si se quiere, "injertando" a Dioniso en su contexto. No se espere, pues, una nueva interpretación de Dioniso aquí, sino más bien una historia de las interpretaciones. Como se señala con mucho acierto, independientemente la historicidad de los diversos "Dionisos" o "Ur-Dionysos", planteados y recogidos en el estudio, lo que más interesa destacar es precisamente cómo han influido esas interpretaciones en nuestra apropiación del mundo antiguo como modelo explicativo, en lo psicológico y lo antropológico, de modo que el distante Dioniso nos sigue proporcionando un conocimiento cercano del hombre actual. Lo cual, en definitiva, sigue siendo, como lo era ya en la antigüedad, una de las prerrogativas de este dios, vecino y ajeno, entre dos mundos, con sus ritos y máscaras.

David Hernández de la Fuente

UNED

dhdelafuente@geo.uned.es

Fecha de recepción: 15 de noviembre de 2014.

Fecha de aceptación: 1 de diciembre de 2014.

Publicado: 31 de diciembre de 2014.

Para citar: Diego Mariño Sánchez, "Injertando a Dioniso. Las interpretaciones del dios, de nuestros días a la Antigüedad. Madrid: Siglo XXI, 2014, 414 págs.”, Historiografias, 8 (julio-diciembre, 2014): pp. 154-158.

http://www.unizar.es/historiografias/historiografias/numeros/8/hernandez.pdf 